\title{
ANALISIS KINERJA SEKTOR PERTANIAN DALAM PEREKONOMIAN WILAYAH DI KOTA BANJAR
}

\author{
Oleh: \\ Riska Novitasari ${ }^{1}$, Dedi Herdiansah $\mathbf{S}^{2}$, Cecep Pardani ${ }^{3}$ \\ ${ }^{1,3}$ Fakultas Pertanian Universitas Galuh \\ ${ }^{2}$ Fakultas Pertanian Universitas Padjadjaran
}

\begin{abstract}
ABSTRAK
Penelitian ini bertujuan untuk mengetahui: (1) kinerja sektor pertanian dan sektor perekonomian lainnya di Kota Banjar, (2) kinerja subsektor pertanian Kota Banjar, (3) kinerja sektor pertanian dan sektor perekonomian lainnya kedepan di Kota Banjar, (4) kinerja subsektor pertanian kedepan di Kota Banjar, (5) faktor utama yang menetukan kinerja sektor petanian dan subsektor pertanian di Kota Banjar. Jenis penelitian yang digunakan adalah metode analisis data sekunder. Data yang dipergunakan adalah data PDRB Kota Banjar dan PDRB Jawa Barat. Analisis yang digunakan adalah analisis Location Quotient (LQ), Dynamic Location Quotient (DLQ), dan Shift Share. Hasil penelitian ini menunjukkan bahwa:

1. Berdasarkan analisis $L Q$, kinerja sektor pertanian menjadi sektor basis dalam pertumbuhan perekonomian wilayah di Kota Banjar.

2. Berdasarkan analisis $L Q$, subsektor pertanian yang memiliki kinerja sebagai subsektor basis adalah subsektor perkebunan dan subsektor peternakan.

3. Berdasarkan analisis DLQ, kinerja sektor pertanian diperkirakan berubah menjadi sektor non basis dalam pertumbuhan perekonomian wilayah di Kota Banjar.

4. Berdasarkan analisis DLQ, subsektor pertanian yang diperkirakan memiliki kinerja sebagai subsektor basis adalah subsektor perkebunan, peternakan dan perikanan.

5. Berdasarkan analisis shift share, faktor yang menentukan kinerja sektor pertanian dan subsektor tanaman bahan makanan adalah faktor struktur ekonomi, sedangkan faktor yang menentukan kinerja subsektor perkebunan, peternakan, kehutanan dan perikanan di wilayah Kota Banjar adalah faktor lokasi.
\end{abstract}

\section{Kata kunci : kinerja, kota banjar, sektor pertanian}

\section{PENDAHULUAN}

Pembangunan adalah proses yang direncanakan dan merupakan rangkaian kegiatan yang berkesinambungan, berkelanjutan dan bertahap menuju ke tingkat yang lebih baik. Untuk mewujudkan hal tersebut, maka pembangunan harus dilakukan secara bertahap di segala sektor maupun subsektor secara terencana dan terprogram. Menurut Martono (2008), proses pembangunan secara filosofis dapat diartikan sebagai upaya yang sistematis dan berkesinambungan. Proses ini bertujuan menciptakan keadaan yang dapat menyediakan berbagai alternatif untuk pencapaian aspirasi warga.

Indonesia kini tengah membangun melalui berbagai kebijakan, salah satunya kebijakan desentralisasi daerah. Desentralisasi yang merupakan bagian dari reformasi birokrasi yang menjadikan daerah memiliki otonomi untuk mengatur daerahnya sendiri. Otonomi daerah berdasarkan Undang-undang 32 Tahun 2004 sendiri merupakan hak, wewenang dan kebijakan daerah untuk mengatur dan mengurus sendiri urusan pemerintahan dan kepentingan masyarakat setempat sesuai dengan peraturan perundang-undangan. Melalui kebijakan tersebut diharapkan dapat memberikan kesempatan yang besar bagi daerah untuk mengembangkan potensinya masing-masing. Hal ini dikarenakan Indonesia terdiri atas daerah-daerah yang memiliki potensi berbeda yang akhirnya juga memerlukan perlakuan kebijakan yang juga berbeda (Jeany, 2013).

Pertanian di Provinsi Jawa Barat secara umum memiliki potensi yang besar dan variatif, dan didukung oleh kondisi agroekosistem yang cocok untuk pengembangan komoditas pertanian dalam arti luas (tanaman pangan, ternak, ikan dan hutan) (Pemerintah Provinsi Jawa Barat, 2014).

Jawa Barat terbagi ke dalam 18 kabupaten dan 9 kota (BPS Jawa Barat, 2013). Salah satu 
kota yang merupakan daerah otonom di Provinsi Jawa Barat yang posisinya berada diperbatasan dengan Kabupaten Cilacap Jawa Tengah dan merupakan pintu gerbang utama jalur lintas selatan Jawa Barat yaitu Kota Banjar.

Seiring dengan berjalannya otonomi daerah, Kota Banjar dituntut untuk membangun daerahnya dengan berlandasakan kepada kemampuan dan kemandirian daerahnya itu sendiri. Dalam hal ini pemerintah daerah berupaya untuk selalu mendorong masing-masing daerah atau desa untuk mengembangkan sektorsektor ekonomi yang merupakan sektor basis dan mendorong sektor ekonomi non basis menjadi sektor basis. Dengan mengetahui kondisi sektor pertanian yang menjadi basis serta penyebarannya akan memudahkan Pemerintah Daerah dalam mengambil kebijakan-kebijakan pembangunan terkait dengan sektor pertanian. Kebijakan-kebijakan yang diambil oleh Pemerintah Daerah ini diharapkan mampu mempertahankan atau bahkan meningkatkan kembali sektor pertanian menjadi sektor yang memberikan kontribusi yang berarti bagi perekonomian wilayah (Dinas Perhubungan Komunikasi Informatika dan Pariwisata, 2014).

Berdasarkan uraian yang telah dijelaskan di atas penulis tertarik untuk mengetahui kinerja sektor pertanian dan sektor perekonomian lainnya di Kota Banjar, kinerja subsektor pertanian di Kota Banjar, kinerja sektor pertanian dan sektor perekonomian lainnya kedepan di Kota Banjar, kinerja subsektor pertanian kedepan di Kota Banjar, serta mengetahui faktor utama yang menentukan kinerja sektor pertanian dan subsektor pertanian di Kota Banjar.

\section{METODE PENELITIAN \\ Jenis Penelitian}

Jenis penelitian yang digunakan adalah metode analisis data sekunder (Martono, 2010).

\section{Operasionalisasi Variabel}

\section{Kinerja Ekonomi}

Kinerja ekonomi yang dimaksud dalam penelitian ini adalah segala sesuatu yang dimiliki Kota Banjar yang mungkin atau layak dikembangkan.

\section{Location Quotient (LQ)}

Location Quotient (LQ) merupakan salah satu metode yang dapat diterapkan untuk mengidentifikasi apakah suatu sektor atau subsektor ekonomi tergolong kategori basis atau non basis.

\section{Dynamic Location Quotient (DLQ)}

Dynamic Location Quotient merupakan varians dari LQ untuk mengatasi kelemahan LQ, sehingga dapat diketahui reposisi atau perubahan sektoral pada wilayah analisis.

\section{Shift Share Analysis}

Analisis shift share merupakan teknik yang sangat berguna dalam menganalisis perubahan struktur ekonomi daerah dibandingkan dengan perekonomian nasional.

5. Produk Domestik Regional Bruto (PDRB)

Produk Domestik Regional Bruto (PDRB) adalah jumlah nilai tambah barang dan jasa yang dihasilkan dari seluruh kegiatan perekonomian di suatu daerah.

\section{Sektor Perekonomian}

Merujuk kepada data yang dikeluarkan oleh BPS Provinsi di Negara Kesatuan Republik Indonesia terdapat pembagian lapangan usaha dalam PDRB yang dikelompokkan ke dalam 9 sektor, yaitu: sektor pertanian; pertambangan dan penggalian; industri pengolahan; listrik, gas dan air; bangunan; perdagangan, hotel dan restoran; pengangkutan dan komunikasi; keuangan, sewa dan jasa perusahaan; serta jasa-jasa.

7. Sektor Pertanian

Sektor pertanian adalah sektor dimana dalam produksinya berhubungan dengan proses pertumbuhan dan perkembangan tanaman dan atau hewan serta ikan. Sektor pertanian mencakup 5 subsektor, yaitu; subsektor tanaman bahan makanan; perkebunan; peternakan; kehutanan; serta perikanan.

\section{Teknik Pengumpulan Data}

Data yang digunakan dalam penelitian ini adalah data sekunder yang dilakukan melalui studi pustaka dan studi dokumentasi dari Dinas atau Instansi terkait (Dinas Pertanian, BPS, BAPEDA, Perpustakaan dan lain-lain). Data yang dianalisis dalam penelitian ini merupakan data time series yaitu berupa data PDRB Kota Banjar dan data PDRB Jawa Barat menurut lapangan usaha ADHK 2000 selama lima tahun dari tahun 2009 - 2013.

\section{Teknik Penarikan Sampel}

Teknik penarikan sampel dilakukan secara sengaja (purposive) (Sugiyono, 2013). Penarikan sampel dipilih berdasarkan pertimbangan bahwa Kota Banjar berada di perbatasan Provinsi Jawa Barat dengan Provinsi Jawa Tengah, serta merupakan pintu gerbang utama jalur lintas selatan Jawa Barat. 


\section{Rancangan Analisis Data}

\section{Location Quotion (LQ)}

Menurut Arsyad (2009), kinerja sektor pertanian dan sektor perekonomian lainnya serta subsektor pertanian didekati dengan menggunakan analisis LQ (Location Quotient).

Rumus LQ sebagai berikut: $L Q=\frac{\mathrm{vi} / \mathrm{vt}}{\mathrm{Vi} / \mathrm{Vt}}$

Keterangan,

LQ : Location Quotient

vi : PDRB sektor/subsektor i di wilayah analisis

vt $\quad$ : PDRB total di wilayah analisis

Vi : PDRB sektor/subsektor i di wilayah yang lebih tinggi jenjangnya.

$\mathrm{Vt} \quad$ : PDRB total di wilayah yang lebih tinggi jenjangnya

Apabila LQ lebih dari satu (>1), maka sektor/subsektor tersebut merupakan sektor basis, sedangkan apabila LQ lebih kecil atau sama dengan satu $(\leq 1)$, maka sektor/subsektor tersebut merupakan sektor non basis.

\section{Dynamic Location Quotion (DLQ)}

Menurut Suyatno (2000), penentuan sektor basis yang akan terjadi pada masa yang akan datang pada sektor pertanian dan sektor perekonomian lainnya serta subsektor pertanian digunakan analisis Dynamic Location Quotient (DLQ).

Rumus DLQ sebagai berikut:

$$
D L Q=\left[\frac{(1-g i j) /(1-g j)}{(1-G i) /(1-G)}\right]^{t}
$$

\section{Keterangan,}

DLQ : Dynamic Location Quotient

gij : Rata-rata laju pertumbuhan PDRB sektor/subsektor i di daerah (j)

gj : Rata-rata laju pertumbuhan (PDRB) total sektor di daerah (j)

$\mathrm{Gi} \quad$ : Rata-rata laju pertumbuhan PDRB sektor/subsektor i di daerah (k)

G : Rata-rata laju pertumbuhan (PDRB) total sektor di daerah $(\mathrm{k})$

$\mathrm{t} \quad$ : database rentang tahun proyeksi (lima tahun)

Apabila DLQ lebih dari satu (>1), maka sektor/subsektor tersebut masih dapat diharapkan menjadi sektor basis pada masa yang akan datang, tetapi apabila DLQ kurang dari atau sama dengan satu $(\leq 1)$, maka sektor/subsektor tersebut tidak dapat diharapkan menjadi sektor basis pada masa yang akan datang.

\section{Shift Share Anaysis}

Menurut Suyatno (2000), penentuan faktor penyebab kinerja sektor pertanian dan sektor perekonomian lainnya serta subsektor pertanian digunakan analisis shift share dengan rumus sebagai berikut:

Rumus Shift Share:

$$
\begin{aligned}
\mathrm{TSS}= & \sum\left(\mathrm{g}_{\mathrm{n}}-\mathrm{g}_{\text {in }}\right) \mathrm{X}_{\text {ino }}+\sum\left(\mathrm{G}_{\mathrm{i}}-\mathrm{G}\right) \mathrm{X}_{\text {ino }}+\sum\left(\mathrm{g}_{\text {in }}\right. \\
& \left.-\mathrm{G}_{\mathrm{i}}\right) \mathrm{X}_{\text {ino }} \\
\mathrm{SSS}= & \sum\left(\mathrm{g}_{\mathrm{n}}-\mathrm{g}_{\text {in }}\right) \mathrm{X}_{\text {ino }}+\sum\left(\mathrm{G}_{\mathrm{i}}-\mathrm{G}\right) \mathrm{X}_{\text {ino }} \\
\mathrm{LSS}= & \sum\left(\mathrm{g}_{\text {in }}-\mathrm{G}_{\mathrm{i}}\right) \mathrm{X}_{\text {ino }}
\end{aligned}
$$

\section{Keterangan,}

TSS : Total Shift Share

SSS : Structural Shift Share

LSS : Locational Shift Share

$\mathrm{g}_{\mathrm{n}} \quad$ : Rata-rata laju pertumbuhan (PDRB) total sektor di daerah (j)

$\mathrm{g}_{\text {in }}$ : Rata-rata laju pertumbuhan PDRB sektor/subsektor i di daerah (j)

$\mathrm{G}_{\mathrm{i}}$ : Rata-rata laju pertumbuhan PDRB sektor/subsektor i di daerah (k)

$\mathrm{G}$ : Rata-rata laju pertumbuhan (PDRB) total sektor di daerah $(\mathrm{k})$

$X_{\text {ino }} \quad$ : PDRB sektor i di daerah (j) pada tahun awal

Apabila nilai SSS > LSS berarti faktor yang paling menentukan kinerja sektor/subsektor i adalah faktor struktur ekonominya. Apabila nilai SSS < LSS berarti faktor yang paling menentukan kinerja sektor/subsektor i adalah faktor lokasinya. Sedangkan apabila nilai SSS = LSS berarti faktor struktur ekonomi dan faktor lokasi sama-sama kuat dalam menentukan kinerja sektor/subsektor i.

\section{Tempat dan Waktu Penelitian}

Penelitian ini dilaksanakan di Kota Banjar mulai pada bulan Maret sampai Juli 2015.

\section{HASIL DAN PEMBAHASAN}

\section{Kinerja Sektor Pertanian dan Sektor Perekonomian Lainnya di Kota Banjar}

Sektor basis mendominasi sektor-sektor perekonomian di Kota Banjar, namun nilai LQ ini mengalami fluktuasi dengan kecenderungan menurun selama kurun waktu penelitian. Sektorsektor yang termasuk kedalam sektor basis meliputi sektor pertanian, sektor bangunan dan kontruksi, sektor perdagangan, hotel dan restoran, sektor pengangkutan dan komunikasi, sektor keuangan, persewaan dan jasa perusahaan, serta sektor jasa-jasa. Sedangkan sektor-sektor yang merupakan sektor non basis meliputi sektor pertambangan dan penggalian, sektor industri pengolahan, serta sektor listrik, gas dan air bersih. Hal ini dapat dilihat pada Tabel 1 berikut ini: 
Tabel 1.

Nilai LQ Sektor Pertanian dan Sektor Perekonomian Lainnya di Kota Banjar Tahun 2009 - 2012

\begin{tabular}{|c|c|c|c|c|c|c|c|c|}
\hline \multirow{2}{*}{ No. } & \multirow{2}{*}{ Lapangan Usaha } & \multicolumn{5}{|c|}{ Tahun } & \multirow{2}{*}{ Rata2 } & \multirow{2}{*}{ Ket } \\
\hline & & 2009 & 2010 & 2011 & 2012 & 2013 & & \\
\hline 1. & Pertanian & 1,46 & 1,53 & 1,59 & 1,56 & 1,51 & 1,53 & Basis \\
\hline 2. & Pertambangan \& penggalian & 0,12 & 0,12 & 0,12 & 0,13 & 0,14 & 0,13 & Non Basis \\
\hline 3. & Industri Pengolahan & 0,27 & 0,28 & 0,28 & 0,30 & 0,30 & 0,28 & Non Basis \\
\hline 4. & Listrik, gas \& air bersih & 0,45 & 0,45 & 0,47 & 0,46 & 0,45 & 0,46 & Non Basis \\
\hline 5. & Bangunan \& Konstruksi & 1,57 & 1,48 & 1,41 & 1,35 & 1,37 & 1,44 & Basis \\
\hline 6. & Perdagangan, hotel \& restoran & 1,61 & 1,56 & 1,54 & 1,52 & 1,52 & 1,55 & Basis \\
\hline 7. & Pengangkutan \& komunikasi & 1,63 & 1,47 & 1,35 & 1,31 & 1,28 & 1,41 & Basis \\
\hline 8. & $\begin{array}{l}\text { Keuangan, persewaan } \& \text { jasa } \\
\text { perusahaan }\end{array}$ & 2,04 & 1,93 & 1,83 & 1,78 & 1,76 & 1,87 & Basis \\
\hline 9. & Jasa-jasa & 2,23 & 2,15 & 2,09 & 2,03 & 2,07 & 2,11 & Basis \\
\hline
\end{tabular}

Berdasarkan hasil analisis LQ, nilai LQ terbesar didapat oleh sektor jasa-jasa sebesar 2,11 yang artinya bahwa kemampuan daerah Kota Banjar pada waktu penelitian didominasi oleh sektor jasa-jasa, sedangkan untuk sektor pertaniannya sendiri mulai tahun 2009 sampai tahun 2011 mengalami kenaikan dari 1,46 menjadi 1,59 namun kemudian mengalami penurunan sampai tahun 2013 menjadi sebesar 1,51. Hal itu terjadi karena adanya fenomena alam yang fluktuatif dimana curah hujan yang tinggi pada awal dan akhir tahun 2013 serta kemarau panjang dipertengahan tahun 2013. Selain itu, adanya kenaikan harga bahan bakar minyak pada pertengahan tahun 2013 juga mempengaruhi terhadap kinerja sektor pertanian.

\section{Kinerja Subsektor Pertanian di Kota Banjar}

Berikut ini adalah hasil analisis dengan menggunakan metode LQ (Location Quotient) untuk menentukan subsektor pertanian yang merupakan subsektor basis di Kota Banjar.

Tabel 2.

Nilai LQ Subsektor Pertanian Kota Banjar

\begin{tabular}{|c|c|c|c|c|c|c|c|c|}
\hline \multirow{2}{*}{ No. } & \multirow{2}{*}{ Lapangan Usaha } & \multicolumn{5}{|c|}{ Tahun } & \multirow{2}{*}{ Rata2 } & \multirow{2}{*}{ Ket } \\
\hline & & 2009 & 2010 & 2011 & 2012 & 2013 & & \\
\hline 1. & $\begin{array}{l}\text { Tanaman Bahan } \\
\text { Makanan }\end{array}$ & 0,73 & 0,74 & 074 & 0,72 & 0,71 & 0,73 & Non Basis \\
\hline 2. & Perkebunan & 2,30 & 2,40 & 2,30 & 2,29 & 2,33 & 2,32 & Basis \\
\hline 3. & Peternakan & 2,32 & 2,26 & 2,28 & 2,34 & 2,43 & 2,33 & Basis \\
\hline 4. & Kehutanan & 0,58 & 0,50 & 0,49 & 0,54 & 0,58 & 0,54 & Non Basis \\
\hline 5. & Perikanan & 0,24 & 0,24 & 0,24 & 2,25 & 0,24 & 0,24 & Non Basis \\
\hline
\end{tabular}

Tabel 2 menunjukkan bahwa subsektor pertanian yang merupakan subsektor basis di Kota Banjar yaitu subsektor perkebunan dan peternakan dengan perolehan nilai LQ masingmasing subsektor sebesar 2,32 dan 2,33. Subsektor perkebunan dan subsektor peternakan dikatakan basis karena subsektor tersebut masuk ke dalam kategori komoditi unggulan di Kota Banjar. Dari subsektor perkebunan, komoditinya adalah kakao, karet, kopi, kelapa dan cengkeh. Sementara subsektor peternakan yang menjadi komoditi unggulannya adalah sapi, domba, kambing, kerbau dan kuda. Sedangkan subsektor pertanian yang merupakan subsektor non basis di Kota Banjar yaitu subsektor tanaman bahan makanan, subsektor kehutanan dan subsektor perikanan.

Subsektor tanaman bahan makanan menjadi subsektor non basis dikarenakan berdasarkan hasil sensus pertanian 2013, jumlah rumah tangga yang bergerak dalam subsektor usahanya tidak atau belum panen selama periode Mei 2012 sampai April 2013 diakibatkan mengalami puso (hasil panen kurang dari 11 persen dari keadaan normal). 
Kinerja Sektor Pertanian dan Sektor Perekonomian Lainnya Kedepan di Kota Banjar

Kinerja sektor pertanian dan sektor perekonomian lainnya di Kota Banjar untuk lima tahun kedepan terhitung dari tahun 2014 sampai tahun 2018 cenderung banyak mengalami perubahan posisi. Untuk sektor pertambangan dan penggalian, sektor industri pengolahan, terjadi perubahan kinerja dari non basis menjadi basis. Sedangkan sektor-sektor perekonomian lainnya yang menjadi non basis yaitu: sektor pertanian, sektor listrik, gas dan air bersih, sektor bangunan dan konstruksi, sektor perdagangan, hotel dan restoran, sektor pengangkutan dan komunikasi, sektor keuangan, persewaan dan jasa perusahaan serta sektor jasa-jasa.

Tabel 3.

Nilai DLQ Sektor Pertanian dan Sektor Perekonomian Lainnya di Kota Banjar

\begin{tabular}{|c|c|c|c|c|c|c|c|}
\hline \multirow{2}{*}{ No. } & \multirow{2}{*}{ Lapangan Usaha } & \multicolumn{5}{|c|}{ DLQ $=[(1+\text { gij }) /(1+g j) /(1+G i) /(1+G)]^{\wedge} t$} & \multirow{2}{*}{ Ket } \\
\hline & & 2014 & 2015 & 2016 & 2017 & 2018 & \\
\hline 1. & Pertanian & 0,66 & 0,43 & 0,28 & 0,18 & 0,12 & Non Basis \\
\hline 2. & Pertambangan \& penggalian & 6,32 & 39,89 & 251,90 & $1.590,88$ & $10.047,26$ & Basis \\
\hline 3. & Industri Pengolahan & 1,81 & 3,27 & 5,91 & 10,68 & 19,31 & Basis \\
\hline 4. & Listrik, gas \& air bersih & 0,76 & 0,57 & 0,43 & 0,33 & 0,25 & Non Basis \\
\hline 5. & Bangunan \& Konstruksi & 0,81 & 0,65 & 0,52 & 0,42 & 0,34 & Non Basis \\
\hline 6. & Perdagangan, hotel \& restoran & 0,82 & 0,68 & 0,56 & 0,46 & 0,38 & Non Basis \\
\hline 7. & Pengangkutan \& komunikasi & 0,51 & 0,26 & 0,14 & 0,07 & 0,04 & Non Basis \\
\hline 8. & $\begin{array}{l}\text { Keuangan, persewaan } \& \text { jasa } \\
\text { perusahaan }\end{array}$ & 0,62 & 0,39 & 0,24 & 0,15 & 0,09 & Non Basis \\
\hline 9. & Jasa-jasa & 0,73 & 0,53 & 0,38 & 0,28 & 0,20 & Non Basis \\
\hline
\end{tabular}

Sektor yang memperoleh nilai DLQ terbesar yaitu sektor pertambangan dan penggalian dengan nilai DLQ sebesar 10.047,26. Yang berkontribusi untuk sektor pertambangan dan penggalian di Kota Banjar adalah sektor penggalian. Sektor penggalian merupakan sektor penunjang pada sektor lainnya, diantaranya seperti sebagai bahan baku pembuatan industri bata merah dan penunjang kegiatan sektor konstruksi. Bahan galian yang utama di Kota Banjar adalah andesit, pasir dan tanah liat. Laju pertumbuhan PDRBnya pada tahun 2013 sebesar 3,88 persen lebih besar dibandingkan pada tahun 2012 yang hanya 0,06 persen, bahkan apabila dibandingkan dengan laju pertumbuhan PDRB di tingkat Provinsi pada tahun yang sama hanya sebesar -0,66 persen, maka perbedaanya jauh lebih besar karena di tingkat Provinsi nilainya menunjukkan trend yang negatif yang artinya bahwa di Jawa Barat sektor pertambangan dan penggalian mengalami kemerosotan. Laju pertumbuhan PDRB sektor pertambangan dan penggalian sejak tahun 2012 sampai 2013 juga melebihi laju pertumbuhan PDRB sektor pertanian yang ada di Kota Banjar itu sendiri, yang sejak tahun 2012 sampai 2013 sektor pertanian tetap menunjukkan trend yang negatif.
Sektor pertanian pada lima tahun yang akan datang diperkirakan menjadi non basis. Itu dikarenakan semakin berkurangnya potensi sumber daya alam dan bertambahnya alih fungsi lahan produktif menjadi area pemukiman dan industri. Selain itu, proses pergeseran struktur ekonomi dari primer ke sekunder dan tersier yang tidak dapat dihindari. Hal ini merupakan ciri suatu "kota" yang sedang membangun dimana terjadi perubahan dominasi dari rural characteristics yang identik dengan usaha yang padat karya (labor intensive) menuju urban characteristics yang identik dengan usaha padat modal (capital intensive).

\section{Kinerja Subsektor Pertanian Kedepan di Kota Banjar}

Hasil analisis DLQ terhadap subsektor pertanian Kota Banjar akan menunjukan apakah subsektor tersebut mengalami peningkatan kinerja, penurunan atau kinerjanya stabil di masa sekarang dan pada masa yang akan datang pada rentang waktu lima tahun (2014 - 2018). Hasil analisis tersebut dapat dilihat pada Tabel 4 berikut ini: 
Tabel 4.

Nilai DLQ Subsektor Pertanian Kota Banjar

\begin{tabular}{|c|c|c|c|c|c|c|c|}
\hline \multirow[t]{2}{*}{ No. } & \multirow[t]{2}{*}{ Lapangan Usaha } & \multicolumn{5}{|c|}{ 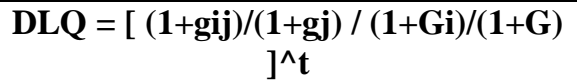 } & \multirow[t]{2}{*}{ Ket } \\
\hline & & 2014 & 2015 & 2016 & 2017 & 2018 & \\
\hline 1. & Tanaman Bahan Makanan & 0,68 & 0,46 & 0,32 & 0,22 & 0,15 & Non Basis \\
\hline 2. & Perkebunan & 1,44 & 2,08 & 3,00 & 4,32 & 6,22 & Basis \\
\hline 3. & Peternakan & 2,21 & 4,90 & 10,86 & 24,05 & 53,27 & Basis \\
\hline 4. & Kehutanan & $-0,37$ & 0,14 & $-0,05$ & 0,02 & $-0,01$ & Non Basis \\
\hline 5. & Perikanan & 1,48 & 2,19 & 3,25 & 4,82 & 7,14 & Basis \\
\hline
\end{tabular}

Tabel 4 menunjukkan bahwa pada masa yang akan datang diperkirakan subsektor perkebunan, peternakan dan perikanan yang akan menjadi subsektor basis. Nilai DLQ yang diperoleh dari subsektor peternakan yaitu sebesar 53,27. Subsektor peternakan pada tahun 2013 meningkat jumlahnya dibandingkan tahun 2012 . Untuk ternak sapi misalnya, dari tahun 2012 sebanyak 1.256 ekor menjadi 1.270 ekor pada tahun 2013. Sedangkan subsektor pertanian yang merupakan subsektor non basis adalah subsektor tanaman bahan makanan dan kehutanan.

Subsektor perikanan diperkirakan mengalami perubahan posisi dari non basis menjadi basis dikarenakan walaupun mengalami perlambatan laju pertumbuhan tetapi nilainya masih menunjukkan trend yang positif, artinya kontribusi untuk sektor pertanian di Kota Banjar pada waktu penelitian (2009 - 2013) masih terus mengalami kenaikan. Kegiatan usaha pertanian di subsektor perikanan terdiri dari kegiatan budidaya ikan dan penangkapan ikan. Jenis ikan utama yang mendominasi kegiatan budidaya ikan adalah ikan mujaer. Jenis ikan ini merupakan jenis ikan yang dikembangkan dan masuk dalam Rencana Strategis (Renstra) Kementrian Kelautan dan Perikanan.

\section{Faktor Utama Penentu Kinerja Sektor dan Subsektor Pertanian di Kota Banjar}

Faktor utama penentu kinerja sektor pertanian dan subsektor pertanian di Kota Banjar dapat dilihat pada Tabel 5 berikut ini:

Tabel 5.

Analisis Shift Share Sektor dan Subsektor Pertanian di Kota Banjar

\begin{tabular}{|c|l|r|r|c|}
\hline No. & \multicolumn{1}{|c|}{ Lapangan Usaha } & \multicolumn{1}{c|}{ SSS } & \multicolumn{1}{c|}{ LSS } & Faktor Penentu \\
\hline 1. & Sektor Pertanian & $159.287,33$ & $-241.795,87$ & Struktur Ekonomi \\
\hline Subsektor Pertanian & & \\
\hline a. & Tanaman Bahan Makanan & $75.244,49$ & $-209.507,39$ & Struktur Ekonomi \\
\hline b. & Perkebunan & $-19.724,60$ & $-10.434,03$ & Faktor Lokasi \\
\hline c. & Peternakan & $-107.915,44$ & $34.581,60$ & Faktor Lokasi \\
\hline d. & Kehutanan & $-3.414,15$ & $2.235,60$ & Faktor Lokasi \\
\hline e. & Perikanan & $-1.471,73$ & $-1.390,34$ & Faktor Lokasi \\
\hline
\end{tabular}

Tabel 5 menunjukkan bahwa sektor pertanian memiliki nilai SSS yang lebih besar dari LSS, hal ini menunjukkan bahwa faktor struktur ekonomi merupakan faktor utama penentu perubahan kinerja. Kota Banjar pada awalnya merupakan salah satu kecamatan di Kabupaten Ciamis yang dominan wilayahnya merupakan wilayah perdesaan. Namun wilayah Kecamatan Banjar menunjukkan perkembangan dan kemajuan dengan ciri dan sifat kehidupan perkotaan, sehingga wilayah Banjar berubah status menjadi Kota Adminsitratif. Sebagai daerah perkotaan dengan ciri dan sifat kehidupan perkotaan, cepat atau lambat Kota Banjar akan mengalami pergeseran struktur ekonomi. Hal ini mengakibatkan tingginya tingkat peralihan lahan usaha pertanian menjadi lahan non pertanian.

Sedangkan untuk subsektor pertanian sendiri, subsektor tanaman bahan makanan memiliki nilai SSS lebih besar daripada nilai LSS, artinya faktor struktur ekonomi merupakan faktor utama yang mempengaruhi kinerja. Subsektor perkebunan, peternakan, kehutanan dan perikanan memiliki nilai SSS lebih kecil daripada LSS sehingga faktor yang mempengaruhi kinerja adalah faktor lokasi. 


\section{KESIMPULAN DAN SARAN}

\section{Kesimpulan}

Berdasarkan hasil penelitian dan pembahasan, maka dapat disimpulkan sebagai berikut:

1. Berdasarkan analisis LQ, selama tahun 2009 2013 kinerja sektor pertanian menjadi sektor basis dalam pertumbuhan perekonomian wilayah di Kota Banjar setara dengan sektor bangunan dan konstruksi; perdagangan, hotel dan restoran; pengangkutan dan komunikasi; keuangan, persewaan dan jasa perusahaan; serta jasa-jasa. Sedangkan sektor pertambangan dan penggalian; industri pengolahan; dan sektor listrik, gas dan air bersih merupakan sektor non basis di wilayah Kota Banjar.

2. Berdasarkan analisis LQ, subsektor pertanian yang memiliki kinerja sebagai subsektor basis dari tahun 2009 - 2013 adalah subsektor perkebunan dan peternakan. Sedangkan subsektor pertanian yang memiliki kinerja sebagai subsektor non basis adalah subsektor tanaman bahan makanan; kehutanan; dan perikanan.

3. Berdasarkan analisis DLQ, selama lima tahun dari tahun 2014 - 2018 diperkirakan sektor pertambangan dan penggalian; dan sektor industri pengolahan merupakan sektor basis. Sedangkan sektor pertanian; listrik, gas dan air bersih; bangunan dan konstruksi; perdagangan, hotel dan restoran; pengangkutan dan komunikasi; keuangan, persewaan dan jasa perusahaan; serta jasa-jasa merupakan sektor non basis.

4. Berdasarkan analisis DLQ, subsektor pertanian yang diperkirakan yang memiliki kinerja sebagai subsektor basis pada tahun 2014 - 2018 adalah subsektor perkebunan; peternakan; dan perikanan. Sedangkan subsektor tanaman bahan makanan dan kehutanan diperkirakan menjadi subsektor non basis di Kota Banjar.

5. Berdasarkan analisis shift share, faktor yang menentukan kinerja sektor pertanian dan subsektor tanaman bahan makanan adalah faktor struktur ekonomi, sedangkan faktor yang menentukan kinerja subsektor perkebunan, peternakan, kehutanan dan perikanan adalah faktor lokasi.

\section{Saran}

1. Sektor pertanian untuk lima tahun mendatang diperkirakan menjadi sektor non basis. Untuk itu, sektor pertanian yang berbasis lahan diharuskan beralih menjadi sektor pertanian berbasis teknologi untuk mencegah kemerosotan yang terus berlanjut.

2. Pemerintah dan masyarakat di Kota Banjar dihimbau untuk menjaga kelestarian sumber daya alam dengan prinsip berwawasan lingkungan sebagai sarana untuk mencapai keseimbangan pemenuhan kebutuhan bagi generasi sekarang maupun generasi yang akan datang.

3. Hal yang perlu mendapat perhatian terkait investasi yaitu pemerintah harus lebih mengarahkan kepada basis ekonomi yang banyak menggunakan komponen lokal dengan daya saing yang tinggi serta dapat bersinergi dengan usaha yang telah terbentuk.

\section{DAFTAR PUSTAKA}

Arsyad, L. 2009. Pengantar Perencanaan dan Pembangunan Ekonomi Daerah. BPFE UGM. Yogyakarta

Badan Pusat Statistik Jawa Barat. 2013. Produk Domestik Regional Bruto (PDRB) Provinsi Jawa Barat Menurut Lapangan Usaha Tahun 2009 - 2011. Bandung

Badan Pusat Statistik Jawa Barat. 2014. Produk Domestik Regional Bruto (PDRB) Provinsi Jawa Barat Menurut Lapangan Usaha Tahun 2010 - 2012. Bandung

Badan Pusat Statistik Kota Banjar. 2014. Produk Domestik Regional Bruto (PDRB) Kota Banjar Tahun 2014. Banjar

Dinas Perhubungan Komunikasi Informasi dan Pariwisata. 2014. Visi dan Misi Kota Banjar. http://banjarkota.go.id/?Fpage_id=52 (online). Diakses tanggal 18 Maret 2015

Jeany, H. 2013. Jawa Barat: Provinsi Kaya Potensi. http:/m.kompasiana.com/post/read/530287/3 /jawa-barat-provinsi-kaya-potensi.html (online). Diakses tanggal 24 Maret 2015

Martono, N. 2010. Metode Penelitian Kuantitatif: Analisis Isi dan Analisis Data Sekunder (Edisi Revisi). Rajawali Pers. Jakarta

Martono, T. 2008. Ekonomi Pembangunan. LPP UNS dan UNS Press. Surakarta

Pemerintah Provinsi Jawa Barat. 2014. Pertanian.

http://perwakilan.jabarprov.go.id/artikel/16/ 
Jurnal IImiah Mahasiswa AGROINFO GALUH

Volume 2 Nomor 1, September 2015

pertanian (on-line). Diakses tanggal 24 Maret 2015

Sugiyono. 2013. Metode Penelitian Administrasi. Alfabeta. Bandung

Suyatno. 2000. Analisa Economic Base Terhadap Pertumbuhan Ekonomi Daerah Tingkat II Wonogiri: Menghadapi UU No. 22/1999 dan UU No. 5/1999. Jurnal Ekonomi dan Pembangunan Vol.1 No. 2 Desember 2000: 144 - 159. FE Universitas Muhammadiyah Surakarta. Surakarta 